[RAdiocarbon, Vol 22, No. 3, 1980, P 879-884]

\title{
SEARCH FOR PEDOGENIC PHASES DURING THE YOUNGER PLEISTOCENE AND HOLOCENE (SOLTANIEN AND RHARBIEN) OF TUNISIA
}

\author{
H W SCHARPENSEEL, HEINRICH ZAKOSEK*, ULRICH NEUE, \\ and HEINRICH SCHIFFMANN
}

\author{
Ordinariat für Bodenkunde der Universität Hamburg, \\ Hamburg, West Germany
}

\begin{abstract}
Radiocarbon dates, obtained from paleosols, sediments, fossils, and groundwater samples of North Africa and especially, Tunisia, were investigated for information on phases of pedogenesis throughout the younger Pleistocene and Holocene in north and central Tunisia. This paper evaluates available data, while a larger set of new samples is under study, which, hopefully will exhaust the problem and will reveal whether extrapolations such as those made in this paper, eg, phases of pedogenesis from groundwater data, are correct.

Frequency distribution of the dates from groundwaters taken by systematic sampling, as well as from random soil samples from open pits that yielded access to buried paleosols, indicate that organic matter was being produced for 7 or 8 periods. The evidence suggests major pedogenic activity at about $2000 \mathrm{BP}, 4000$ to $6000 \mathrm{BP}$, 8000 to $12,000 \mathrm{BP}$, and perhaps 21,000 to $25,000 \mathrm{BP}$.
\end{abstract}

\section{INTRODUGTION}

The classic concept of pluvial and interpluvial paleoclimatic phases in the Quaternary of xeric and aridic zones of North Africa has been disputed (Rohdenburg, 1970; Butzer, 1971; Rohdenburg and Sabelberg, 1973; Brunnacker, 1973; 1974; Sabelberg, 1977). Dating of paleosols, charcoal, shells, mollusks, and calcareous crusts imply rather a parallelism in tendency between climatic cycles of African subtropics and temperate European areas. Groundwater dates were also interpreted with regard to paleoclimatic pattern (Sonntag and others, 1978).

A number of ${ }^{14} \mathrm{C}$ dates exist from North Africa, which permit age interpretation of landscape elements. Measurements of phases with geomorphodynamic stability or activity (fluctuation of pedogenic and erosional phases) in Iberia and Morocco are described by Fölster and Gaouar (1975) and especially by Rohdenburg (1977), as well as Rohdenburg and Sabelberg (1979). ${ }^{14} \mathrm{C}$ results of soils, paleosols, gravelly main accumulation sediments, younger loess-like blankets, and groundwater samples of Tunisia are reported by Scharpenseel (1972), Scharpenseel and others (1972), Scharpenseel and Zakosek (1979), Brosche and Molle (1975), Brosche, Molle, and Schütz (1976), or Molle and Brosche (1976). Nile terrace dates stem from Fairbridge (1962), and more comprehensive paleoclimatic evaluations of the greater Sahara, including climate curves and histograms of regional ${ }^{14} \mathrm{C}$ dates, undertaken by Geyh and Jäkel (1974; 1977), Jäkel (1978), Sonntag and others (1978, in press), and Pachur (1979). Van Zinderen Bakker (1979) has tried to parallel climatic evolution in northern and southern Africa, based on available ${ }^{14} \mathrm{C}$ ages.

An attempt was made to study all available ${ }^{14} \mathrm{C}$ dates of paleosols, sediments, fossils, and groundwater samples of Tunisia regarding frequency distribution of obtained dates with reference to sample age.

* Institut für Bodenkunde der Universität Bonn, West Germany 
Paleosol dates of a larger collection of new samples are under scrutiny and will substantially expand the reference base.

RESULTS

Figures 1 and 2 indicate frequency versus age of groundwater dates, taken from wells, embedded in Mesozoic (especially Cretaceous), Tertiary and Quaternary formations (Scharpenseel and others, 1972). A high frequency of a certain age period suggests a correlation with humidity and presence of vegetation. Biotic decomposition of vegetation alone may liberate ${ }^{14} \mathrm{CO}_{2}$ dissolved in groundwater. Table 1, in which all available Tunisian ${ }^{14} \mathrm{C}$ dates are summarized, refers to dates of paleosols from north and central Tunisia (Scharpenseel, 1972; Scharpenseel and Zakosek, 1979). Also listed are samples of charcoal, mollusk shells, and calcareous crust, derived from geomorphic sequences in the Djeffara, NUMBER OF DATES

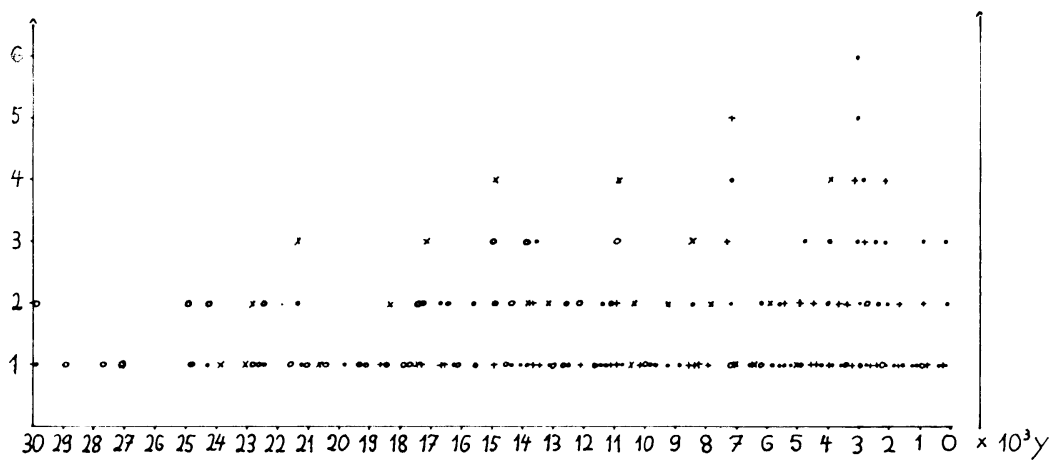

Fig 1. Frequency distribution of groundwater dates (Tunisia)

(• Quaternary, + Tertiary, ○ Cretaceous carrier sediments)

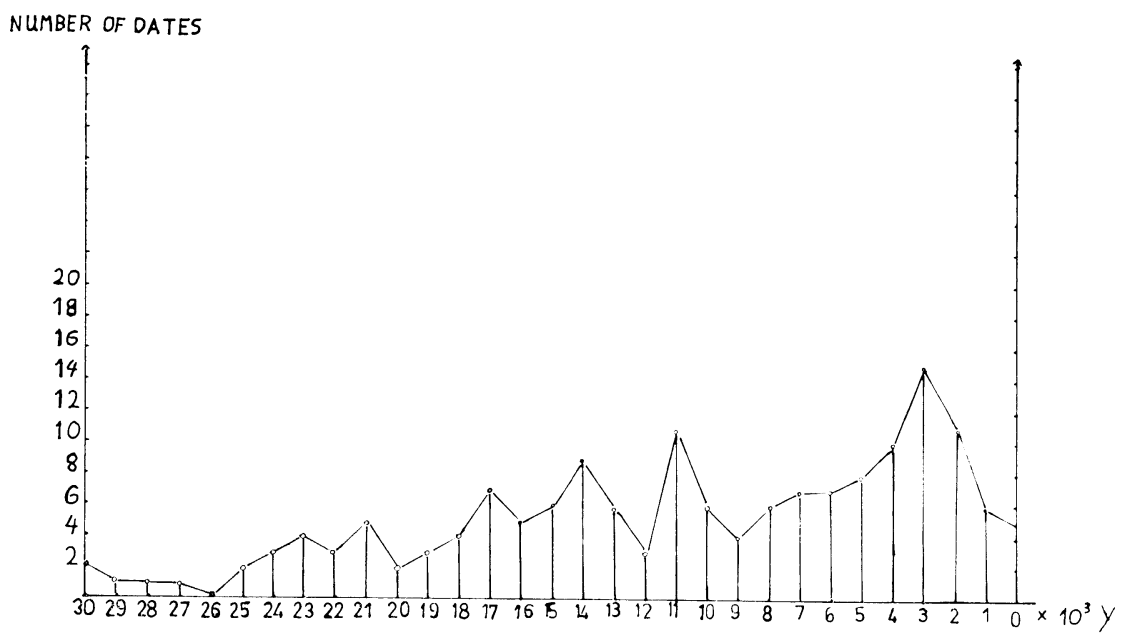

Fig 2. Histogram of groundwater dates (Tunisia) number of dates each full thousand \pm 0.5 thousand years 
TABLE 1

Frequency of dates versus humid phases in Tunisia

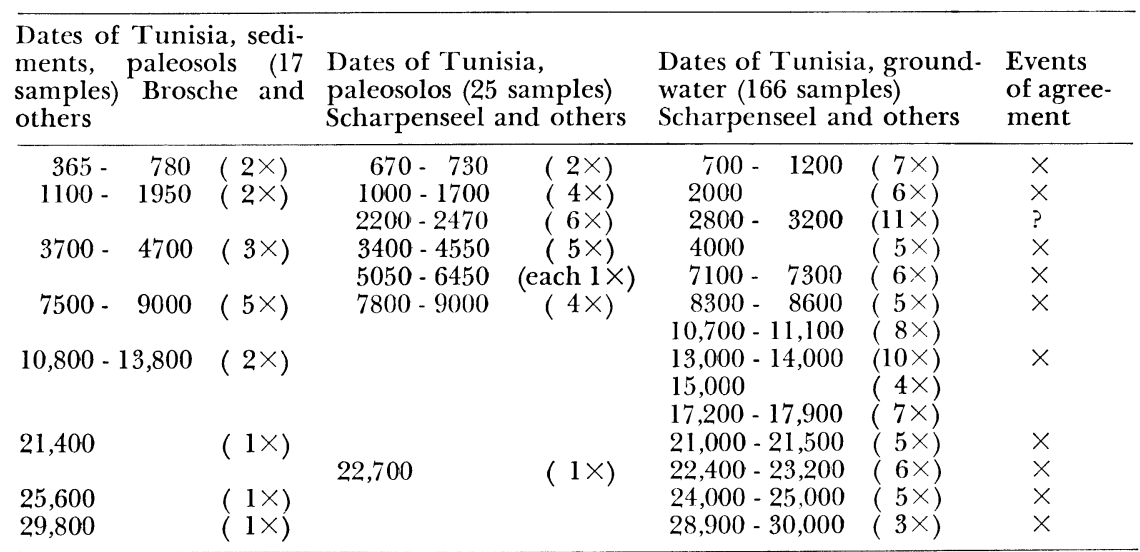

around Matmata (Brosche and Molle, 1975) in the region of the Djebels, Chambi, and Mhrila (Molle and Brosche, 1976), as well as in the Kroumerie East of Tabarka (Brosche, Molle, and Schütz, 1976).

The Tunisia dates indicate that the following periods most probably were characterized by a humid climate and a highly vegetated landscape, with aquifers in sediments.

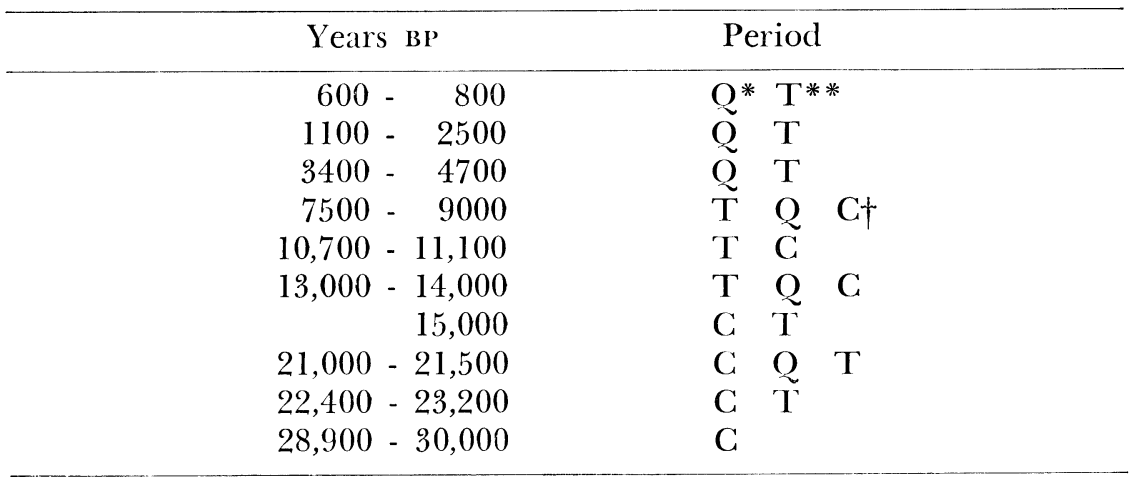

* $\mathrm{Q}=$ Quaternary

** $\widetilde{T}=$ Tertiary

$+\mathrm{C}=$ Cretaceous

Due to the small soil sample number, which agrees well, however, with the few available dates, the following time periods probably fit the same description. They require confirmation from the larger second set of samples, presently under study.

$\begin{array}{rr}2800-3200 & \text { Q T } \\ 5000-6400 & \text { Q T } \\ 17,200-17,900 & \text { C T } \\ 24,000-25,000 & \text { C T }\end{array}$


Compared with paleoclimatic schemes, conceived by various authors for the greater Sahara (fig 3), the Tunisian dates collected by Brosche and others and Scharpenseel and others, representing moisture and vegetation, deviate from the Saharan paleoclimatic setting.

\begin{tabular}{cclcc}
\hline Period & Climate & \multicolumn{1}{c}{ Authors } & Period Climate & \multicolumn{1}{c}{ Authors } \\
\hline $3700-4700$ & humid & $\begin{array}{l}\text { Brosche and } 3700-4700 \\
\text { Geyh }\end{array}$ \\
$3400-4500$ & humid & $\begin{array}{l}\text { Scharpenseel } \\
\text { and others } \\
\text { Scharpenseel 2800-3300 arid Jäkel } \\
\text { and others }\end{array}$ \\
$2800-3200$ & humid & & \\
\hline
\end{tabular}

Good agreement exists among preliminary Tunisian paleosol dates, Tunisian groundwater, charcoal, mollusk, and calcrete dates. The Saharan date collection is obtained for the following age ranges.

\begin{tabular}{|c|c|c|c|}
\hline Period & Authors & Period & Authors \\
\hline $1100-2500$ & $\begin{array}{l}\text { Brosche } \\
\text { and others } \\
\text { Scharpenseel } \\
\text { and others }\end{array}$ & $1500-2500$ & Geyh and Jäkel \\
\hline $5000-6400$ & $\begin{array}{l}\text { Scharpenseel } \\
\text { and others }\end{array}$ & $5000-6000$ & $\begin{array}{l}\text { Sonntag and } \\
\text { others }\end{array}$ \\
\hline \multirow[t]{2}{*}{$7500-9000$} & $\begin{array}{l}\text { Brosche } \\
\text { and others }\end{array}$ & $6700-8500$ & $\begin{array}{l}\text { Flohn; Sonntag } \\
\text { and others }\end{array}$ \\
\hline & $\begin{array}{l}\text { Scharpenseel } \\
\text { and others }\end{array}$ & $\begin{array}{l}8500-10,000 \\
7000-11,000\end{array}$ & Jäkel; Fairbridge \\
\hline \multirow[t]{2}{*}{$10,700-11,100$} & $\begin{array}{l}\text { Brosche } \\
\text { and others }\end{array}$ & $7000-11,000$ & $\begin{array}{l}\text { Flohn; Sonntag } \\
\text { and others }\end{array}$ \\
\hline & $\begin{array}{l}\text { Scharpenseel } \\
\text { and others }\end{array}$ & $\begin{array}{r}8000-12,500 \\
10,800-11,200\end{array}$ & $\begin{array}{l}\text { Jäkel; Fairbridge } \\
\text { Rohdenburg }\end{array}$ \\
\hline \multirow[t]{2}{*}{$13,000-14,000$} & $\begin{array}{l}\text { Brosche } \\
\text { and others }\end{array}$ & $13,000-14,000$ & Jäkel \\
\hline & $\begin{array}{l}\text { Scharpenseel } \\
\text { and others }\end{array}$ & $12,500-16,000$ & \\
\hline 15,000 & $\begin{array}{l}\text { Scharpenseel } \\
\text { and others }\end{array}$ & $14,500-16,000$ & $\begin{array}{l}\text { Geyh and Jäkel; } \\
\text { Jäkel }\end{array}$ \\
\hline $17,200-17,900$ & $\begin{array}{l}\text { Scharpenseel } \\
\text { and others }\end{array}$ & 17,500 & Rohdenberg \\
\hline $24,000-25,000$ & $\begin{array}{l}\text { Scharpenseel } \\
\text { and others }\end{array}$ & $24,000-25,000$ & Jäkel \\
\hline
\end{tabular}

This paper summarizes the available data on past fluctuations of active pedogenic and erosional phases. Emphasis has been on the soil provinces of Tunisia. Current studies of partially loessic profiles with 


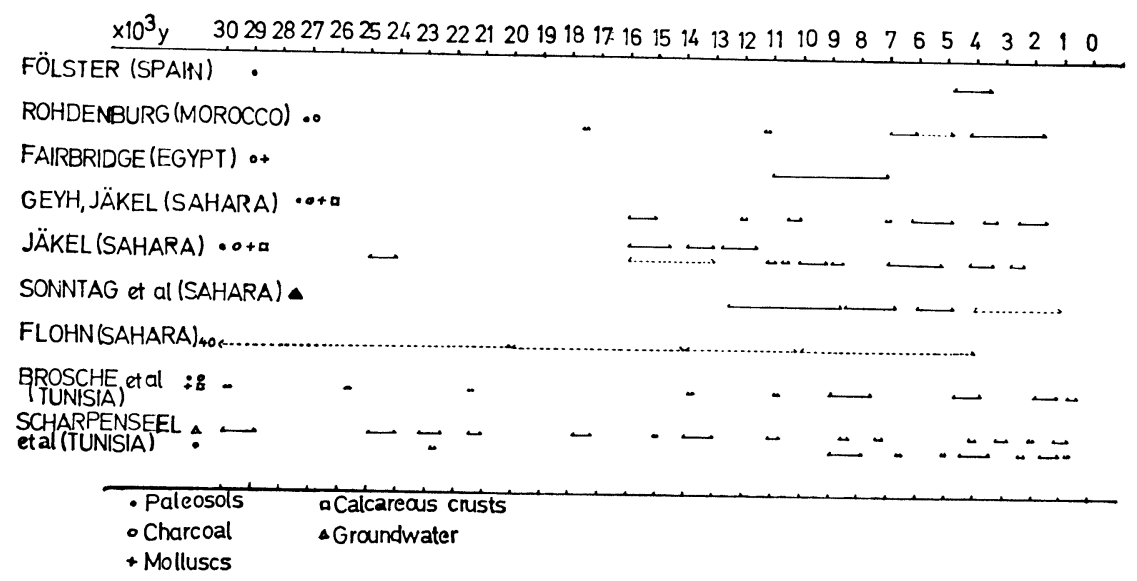

Fig 3. Age spans covered by radiocarbon dates

three and more clearly distinguishable paleosols in central Tunisia will further elucidate the paleoclimatic calendar of this presently xeric and aridic North African region.

The humid spells during the last glacial postulated by us infer the pluvial concept if considerations of stratification, soil genetics, and texture are ignored. Red-brown loamy paleosols from the postglacial, as well as mollic paleosols in Holocene terraces and loessic blankets of central Tunisia suggest a certain parallelism between Tunisian and temperate European paleoclimates (Rohdenburg, 1970; Brunnacker, 1973; Scharpenseel and Zakosek, 1979).

\section{CONCLUSION}

A compilation of available radiocarbon dates pertinent to paleoclimatic fluctuations in Tunisia and North Africa was made. The data suggest humid pedogenic phases especially during the following years BP:

2200 to 2500
3400 to 4700
7100 to 9000
10,800 to 14,000
about 15,000
17,200 to 17,900
21,000 to 25,000
28,900 to 30,000

These intervals are not confirmative sensu strictu for the classic pluvial concept. Neither are they sufficient for its abolishment in favor of more parallel trends to the temperate climate of the past. More information from paleosol dating is, undoubtedly, necessary. 


\section{REFERENCES}

Brosche, K U and Molle, H G, 1975, Morphologische Untersuchungen im nördlichen Matmata - Vorland (nördliche Djeffara, Südtunesien): Eiszeitalter u Gegenwart, v 26, p 218-240.

Brosche, K U, Molle, H G, and Schütz, G, 1976, Geomorphologische Untersuchungen im östlichen Kroumirbergland (Nordtunesien, Gebiet östlich von Tabarka): Eiszeitalter u Gegenwart, v 27, p 143-158.

Brunnacker, K, 1973, Einiges über Lö $\beta$ vorkommen in Tunesien: Eiszeitalter u Gegenwart, v 23/24, p 89-99.

1974, Lösse und Paläoböden der letzten Kaltzeit im mediterranen Raum: Eiszeitalter u Gegenwart, v 25, p 62-95.

Butzer, K W, 1971, Environment and archeology; an ecological approach to prehistory, 2nd ed: Chicago, Aldine, 703 p.

Fairbridge, R W, 1962, New radiocarbon dates of Nile sediments: Nature, v 196, no. 4850, p 108-110.

Fölster, H and Gaouar, A, 1975, Observations on Holocene soil formation and morphodynamic activity in non-calcareous regions of the Iberian peninsula: Catena, v 2, p 365-384.

Geyh, M A and Jäkel, D, 1974, Late glacial and Holocene climatic history of the Sahara desert derived from a statistical assay of ${ }^{14} \mathrm{C}$ dates: Paleogeog, Paleoclimatol, Paleoccol, v 15, p 205-208.

1977, The climate of the Sahara during the late Pleistocene and Holocene on the basis of available radiocarbon dates: Nat Resources Development, Inst Sci Cooperation Tübingen, v 6, p 64-79.

Jäkel, D, 1978, Eine Klimakurve für die Zentralsahara. Sahara, 10.000 Jahre zwischen Weide und Wüste: Handbuch, Ausstellung des Rautenstrauch-Joest-Mus Völkerkunde in Zusammenarbeit, Inst Ur u Frühgeschichte, Univ Köln, Mus Alexander Koenig, Bonn.

Molle, H G and Brosche, K U, 1976, Morphologische und klimageschichtliche Untersuchungen im südöstlichen Vorland des Djebel Mrhila in Zentraltunesien: Die Erde, v 107, p 180-277.

Pachur, $H \mathrm{~J}$, in press, The flat areas of the central Sahara in the early Holocene: Symposium on Sahara and the surrounding seas, 1st, Mainz, April 1979, Proc, in press.

Rohdenburg, H, 1970, Morphodynamische Aktivitäts- und Stabilitätszeiten statt Pluvialund Interpluvialzeiten: Eiszeitalter u Gegenwart, v 21, p 81-96.

1977, Neue ${ }^{14} \mathrm{C}$-Daten aus Marocco and Spanien und ihre Aussagen für die Relief- und Bodenentwicklung im Holozän und Jungpleistozän: Catena, v 4, p 215-228.

Rohdenburg, H and Sabelberg, U, 1973, Quartäre Klimazyklen im westlichen Mediterrangebict und ihre Auswirkungen auf die Relief- und Bodenentwicklung: Catena, v 1, p $71-180$.

in press, Northern Sahara margin (S Morocco): Symposium on Sahara and the surrounding seas, 1st, Mainz, April 1979, Proc, in press.

Sabelberg, U, 1977, The stratigraphic record of late Quaternary accumulation series in south-west Morocco and its consequences concerning the pluvial hypothesis: Catena, v 4, p 209-214.

Scharpensecl, H W, 1972, Messung der natürlichen C-14 Konzentration in der organischen Substanz von rezenten Böden. Eine Zwischenbilanz: Zeitschr Pflanzenernähr, Bodenkunde, v 133, p 241-263.

Scharpenseel, H W, Gewehr, H, Haupenthal, Chr, Kerpen, W, Kruse, E, Ohling, J, Pietig, F, and Tapp, H, 1972: Grundwasseruntersuchungen in Tunesien durch Messung der natürlichen Radiokohlenstoff- und Tritiumkonzentrationen: Fortschr Geol Rheinland u Westfalia, v 21, p 389-412.

Scharpenseel, H W and Zakosek, H, 1979, Phasen der Bodenbildung in Tunesien (Vorabuntersuchungen): Zeitschr Gcomorphol, v 33, p 118-126.

Sonntag, C, Klitzsch, E, El Shazly, E M, Kalinke, Ch, and Münnich, K O, 1978, Paläoklimatische Information im Isotopengehalt ${ }^{14} \mathrm{C}$-datierter Saharawässer: Kontinentaleffekt in D und ${ }^{18} \mathrm{O}$ : Geol Rundschau, Afrikaheft.

Sonntag, C, Thorweihe, U, Rudolph, J, Löhnert, E P, Junghans, Chr, Münnich, K O, Klitzsch, E, El Shazly, E M, and Swailem, F M, in press, Isotopic identification of Saharan groundwater, groundwater formation in the past: Symposium on Sahara and the surrounding seas, 1st, Mainz, April 1979, Proc, in press.

Van Zinderen Bakker, E M, in press, Comparison of the late Quaternary climatic evolution in northern and southern Africa, in Symposium on Sahara and the surrounding seas, 1st, Proc: Mainz, April 1979, in press. 